\title{
Payback Period for Emissions Abatement Alternatives: Role of Regulation and Fuel Prices
}

Zis, Thalis; Angeloudis, Panagiotis; Bell, Michael G. H. ; Psaraftis, Harilaos N.

Published in:

Transportation Research Record

Link to article, DOI:

$10.3141 / 2549-05$

Publication date:

2016

Document Version

Publisher's PDF, also known as Version of record

Link back to DTU Orbit

Citation (APA):

Zis, T., Angeloudis, P., Bell, M. G. H., \& Psaraftis, H. N. (2016). Payback Period for Emissions Abatement Alternatives: Role of Regulation and Fuel Prices. Transportation Research Record, (2549), 37-44. https://doi.org/10.3141/2549-05

\section{General rights}

Copyright and moral rights for the publications made accessible in the public portal are retained by the authors and/or other copyright owners and it is a condition of accessing publications that users recognise and abide by the legal requirements associated with these rights.

- Users may download and print one copy of any publication from the public portal for the purpose of private study or research.

- You may not further distribute the material or use it for any profit-making activity or commercial gain

- You may freely distribute the URL identifying the publication in the public portal 


\title{
Payback Period for Emissions Abatement Alternatives Role of Regulation and Fuel Prices
}

\author{
Thalis Zis, Panagiotis Angeloudis, Michael G. H. Bell, \\ and Harilaos N. Psaraftis
}

\begin{abstract}
As of January 2015, the new maximum limit of fuel sulfur content for ships sailing within emission control areas has been reduced to $0.1 \%$. A critical decision for ship owners in advance of the new limits was the selection of an abatement method that complies with the regulations. Two main options exist: investing in scrubber systems that remove sulfur dioxide emissions from the exhaust and switching to low-sulfur fuel when sailing in regulated waters. The first option would involve significant capital costs, while the latter would lead to operating cost increases because of the higher price of the fuel used. This paper presents a literature review of emissions abatement options and relevant research in the field. A cost-benefit methodology to assess emission reduction investments from ship owners is also presented. A study examined the effects of recent drops in bunker fuel price to the payback period of a potential scrubber investment. The results show that lower prices would significantly delay the payback period of such investments, up to two times in some cases. The case studies present the emissions generation through each option for representative short sea shipping routes. The repercussions of low-sulfur policies on large emission reduction investments including cold ironing are examined, along with implications of slow steaming for their respective payback periods. Recommendations are made for research in anticipation of future regulations and technological improvements.
\end{abstract}

A recurring theme in maritime shipping is the effective management of the sector's environmental impacts. Shipping is considered the most efficient transport mode in carbon emissions per ton kilometer moved (1). Its percentage share of the global anthropogenic carbon dioxide $\left(\mathrm{CO}_{2}\right)$ emissions has declined in recent years from $2.7 \%$ in 2008 (2) to $2.2 \%$ in 2013 (3). In the past few decades, several environmental regulations and policies have been proposed to tackle the issue of air emissions from shipping, some focusing on carbon emissions and other measures targeting other pollutant species. Despite these initiatives, emission outputs have continued

T. Zis and H.N. Psaraftis, Department of Transport, Technical University of Denmark, Bygningstorvet 1, 2800 Kongens Lyngby, Denmark. P. Angeloudis, Centre for Transport Studies, Department of Civil and Environmental Engineering, Imperial College London, London SW7 2BU, United Kingdom. M. G. H. Bell, Institute of Transport and Logistics Studies, University of Sydney Business School, University of Sydney, C37, New South Wales 2006, Australia. Corresponding author: T. Zis, tzis@transport.dtu.dk.

Transportation Research Record: Journal of the Transportation Research Board, No. 2549, Transportation Research Board, Washington, D.C., 2016, pp. 37-44. DOI: 10.3141/2549-05 increasing in absolute terms. Furthermore, maritime transport is not as clean for other pollutant emissions. Bunker fuel used in marine engines is of considerably lower quality than the fuel used in other modes of transport.

The amount of sulfur dioxide $\left(\mathrm{SO}_{2}\right)$ released into the atmosphere through fossil fuel combustion is proportional to the sulfur content of the fuel. As a result, there have been efforts to produce cleaner fuel with lower sulfur content and to regulate the maximum allowed content. The most notable regulation was implemented by the International Maritime Organization (IMO), which has set progressively stricter limits of sulfur content allowed in fuel. IMO has specified designated emission control areas (ECAs), where even tighter limits apply (4). As of January 1, 2015, within such areas, vessels must use fuels of a maximum $0.1 \%$ sulfur content or deploy additional abatement measures that achieve the same reduction in $\mathrm{SO}_{2}$ emissions. Similar strict limits ( $0.1 \%$ maximum since 2008$)$ were set by the European Union for vessels sailing through inland waterways and during port stays longer than $4 \mathrm{~h}$.

Ship owners have the option of either using marine gas oil (MGO), which satisfies the imposed limits, or investing in scrubber systems. Scrubbers are emission control devices installed on board a vessel that treat exhaust gases to remove particulate matter and $\mathrm{SO}_{2}$ emissions. Scrubber systems have significant installation costs but allow the use of bunker fuel, which is cheaper. Therefore, for vessels sailing in ECAs, a critical decision is which abatement solution is economically more beneficial. There is a similar decision problem for vessels calling at ports where the use of low-sulfur fuel is mandatory. An additional option for these vessels is to invest in cold ironing retrofits if the port provides shore power, which in turn depends on the investment costs per cold ironing berth. The ship operator's decision on the use of cold ironing depends on the price of each type of fuel, the costs of installing scrubber systems, the cost of vessel retrofits with cold ironing equipment, and the cost per kilowatt-hour as supplied by the port.

The first section of this paper reviews the literature on the various abatement options. The repercussions of fuel price fluctuations to the shipping sector in recent decades are also discussed. The next section presents a cost-benefit analysis method for the assessment of potential investments. The case studies highlight the importance of trip characteristics and fuel prices and how these can affect the payback time of large investments in abatement technologies. The environmental implications of each decision are considered. The paper concludes with remarks on the significance of the volatility of fuel prices, which may change the effectiveness of proposed regulatory environmental measures. 


\section{LITERATURE REVIEW}

Research in the field has mainly focused on the estimation and reduction of the environmental impacts of the maritime sector through operational practices. Slow steaming is the practice of mitigating fuel costs by reducing sailing speed. It came to prominence after increases in bunker prices in the early 1970s and resurfaced as an option when prices increased in 2008. Most shipping lines have adopted slow steaming, and new vessels are designed to sail at lower speeds. Propulsion engines are typically designed to operate between $70 \%$ and $85 \%$ of their maximum continuous rating where their specific fuel oil consumption (SFOC) is near its minimum value (5). For this reason, and because slow steaming is expected to continue, there have emerged some complementary technological measures. Propulsion engines may be derated to have lower SFOC values at the lower engine loads operated, an action that can be reversed (6). Alternatively, new vessels may be equipped with smaller engines so that their design speed is at a lower level. In both cases, fuel consumption will increase if the vessel needs to increase its speed or when it sails through bad weather at the same speed.

\section{Fuel Price and Its Role in Speed}

Several studies have attempted to calculate the optimal sailing speed of individual vessels or entire fleets to minimize fuel consumption. Shipping lines are expected to continue the practice of slow steaming in the near future, despite the recent drop in fuel prices. Lower sailing speeds for the same transport demand would lead to deployment of additional vessels to satisfy demand. Despite the higher number of vessels deployed, emissions could be lower because of fuel economy, as shown in the literature (7). However, for each vessel there is a breakeven point for bunker price, where for lower prices slow steaming is no longer sustainable (5). This price will also depend on the value of cargo carried, as for more expensive commodities the inventory costs may be more significant than the potential fuel savings of slow steaming, and for such voyages the optimal speed may be higher (5).

The payback time for an investment in technology that allows the use of cheap fuel [e.g., scrubbers or liquefied natural gas (LNG) engines] will depend on the fuel consumption of the engine. An increase in speed would result in more trips per year at higher fuel costs per trip, which in turn would reduce the payback time of such investments.

\section{Market Response and Fuel Availability}

Following the designation of ECAs, several technical studies considered the availability of low-sulfur fuel $(8,9)$ and assessed the feasibility of the alternatives (10). There were concerns about the availability of low-sulfur fuel following the stricter limits in 2015, but studies concluded that the issue initially will be economic, not technical (11). Refineries will have to produce additional low-sulfur fuel to be used in Europe and along the North American coasts. This need is expected to result in new refineries in those countries focusing on the production of low-sulfur fuel and their residual oil being shipped to countries where its use is allowed. This change in supply chains may affect the price differential between fuel types in the coming years.

The response of the market to increasing bunker prices within ECAs was to apply the bunker adjustment factor, a series of sur- charges on freight rates imposed on shippers (12). However, some shipping companies terminated some routes following the new sulfur limits in 2015, as these routes were no longer profitable. A survey conducted by Lloyd's List on sulfur abatement showed that most ship owners were considering use of distillate fuel as the preferred abatement method until 2020. Then, a switch to LNG for new builds or the use of scrubber systems (provided these are proved effective) is the anticipated response (13). At the same time, various shipping companies have started installing scrubber systems in some of their vessels. The decision to retrofit a portion of a company's fleet and use MGO in the remaining vessels may reduce the risk of investing heavily to retrofit all vessels. However, such decisions were taken before the unexpected drop in fuel prices that started in 2014.

\section{Expansion of ECAs and New Regulation Tier}

The major implications of sulfur requirements affect vessels spending part of their journeys within regulated waters. According to the IMO regulation, the maximum allowed sulfur content will be $0.5 \%$ for all regions outside ECAs from 2020, and therefore refineries will have to meet the new levels of demand for low-sulfur fuel. Implementation of the lower limit may be postponed until 2025. The designation of additional ECAs could affect short sea shipping and could lead to modal shifts or longer sailing routes to avoid regulated waters. A case study on a possible designation of the Mediterranean Sea as an ECA predicted an important modal shift toward road or rail modes because of the higher transport costs via maritime routes (14). However, this modal shift could result in lower carbon emissions for some routes because of the shorter distances traveled, the high sailing speeds of specific vessels, and the unutilized capacity of some vessels.

For vessels sailing within and outside ECAs, speed optimization has been suggested to reduce fuel operating costs (15-17). The principle behind speed optimization is the reduction of fuel consumption for pricier MGO by sailing at lower speeds. Increased speeds then make up for lost time in waters where use of heavy fuel oil (HFO) is permitted. The ECA refraction problem has been considered to describe the concept of reducing the necessary length of travel within regulated areas (18). Both problems have been proved to have an economic benefit, but they lead to higher $\mathrm{CO}_{2}$ emissions because of the overall greater fuel consumption. The percentage increase in carbon emissions depends on the relative lengths of segments within and outside ECAs. Speed differentiation will lead to even lower sulfur emissions locally because of the lower activity within the ECA.

Because of the next tier for sulfur limits from 2020 (or 2025) onward, it can be expected that speed differentiation will not have significant savings in the future because of the anticipated lower price differential of fuel used in and out of ECAs. The installation of scrubber systems would make the two-speed optimization problem obsolete as the fuel cost per nautical mile will be the same for all areas.

\section{Abatement Methods}

The options to ensure adherence to regulatory standards include the use of scrubber systems, switching fuel to MGO, and considering dual-fuel engines that can use LNG or rely on shore power for covering energy requirements at berth. The options are summarized in 


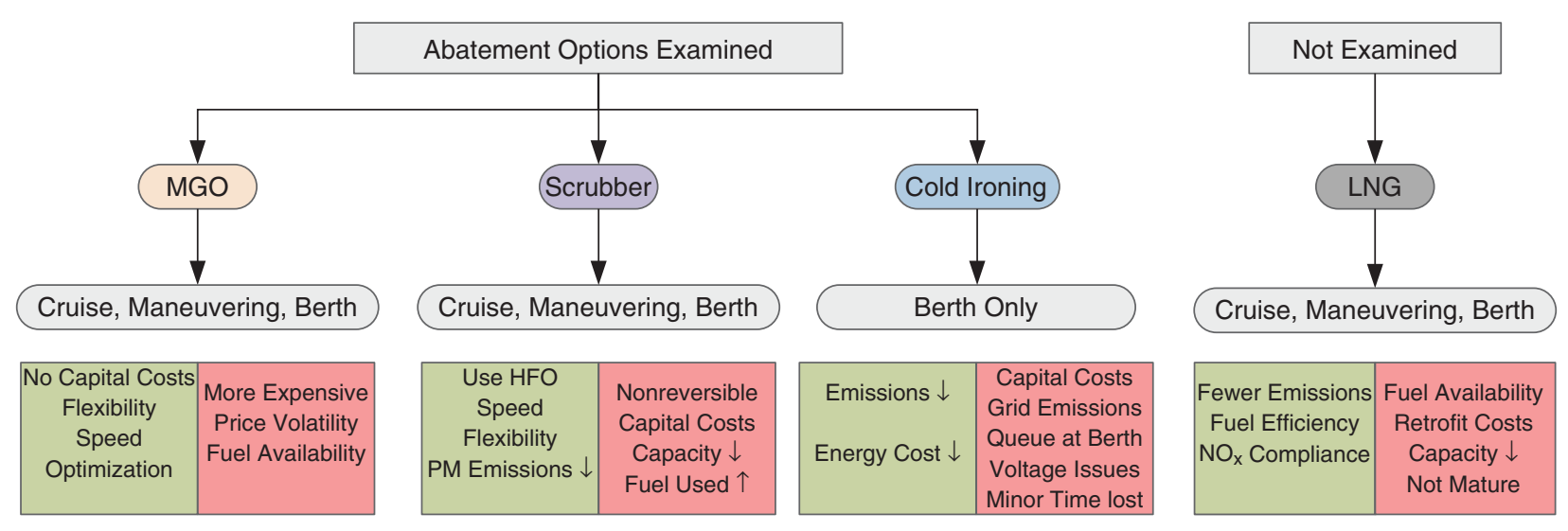

FIGURE 1 Abatement options that comply with sulfur regulation in ECAs and European Union ports.

Figure 1. The figure shows the activities for which each solution can be used and presents their main advantages and disadvantages. The following sections present the solutions in more detail.

\section{Marine Gas Oil}

MGO is pure distillate oil with a sulfur content lower than $0.1 \%$. It is the only fuel that can be used in conventional marine engines within regulated waters. No major modifications are needed for marine engines to run on MGO. However, fuel must be stored in different tanks when a vessel uses two types. Switching to MGO may affect the engine's performance. MGO has a lower viscosity, and there may be need for additional lubrication to avoid damage to the engine's fuel pumps. Such impacts are not considered in this paper.

Historically, MGO has been more expensive than HFO because MGO is more highly processed. Forecasting future fuel prices and price differentials between fuel types is difficult (19). MGO is expected to increase in price faster than HFO because of the higher demand for low-sulfur fuel (20). In 2013 the price difference was $\$ 230$ per ton (MGO was $43 \%$ more expensive), whereas following the recent drop in crude oil price this difference is now \$178 [MGO is $56 \%$ more expensive (www.bunkerworld.com)]. The current MGO price is similar to that of HFO 2 years ago. Feasibility studies had predicted a constant increase in fuel prices, which may have made scrubber systems and cold ironing more attractive options.

\section{Scrubber Systems}

The main principle of a scrubber system is to filter the exhaust gases through water to neutralize the sulfur oxides $\left(\mathrm{SO}_{\mathrm{x}}\right)$ resulting in sulfates. Three main types of scrubber systems are available, depending on the origin of the water used to wash out $\mathrm{SO}_{\mathrm{x}}$ :

- Seawater scrubbing,

- Freshwater scrubbing, and

- Hybrid systems.

The first type uses seawater to neutralize acidic exhaust gases, whereas in waters where alkalinity is too low (e.g., in the Baltic Sea or Alaska), freshwater scrubbers must be used (21). Hybrid systems allow changes in the water used. Scrubbers can be installed on new builds, and older vessels can be retrofitted. Retrofitting a vessel typically costs more and will reduce the capacity of the vessel because of the space required for the installation. The study presented in this paper considered only freshwater scrubbers as a retrofit option for a vessel.

Freshwater scrubbers are reported to reduce $\mathrm{SO}_{\mathrm{x}}$ by up to $97 \%$ and particulate matter emissions by about $30 \%$ to $60 \%$ when HFO containing $3.5 \%$ sulfur is used (8). However, the use of scrubber systems requires energy, and therefore an increase in the overall fuel consumption per trip is expected. This increase is estimated as a range of $1 \%$ to $3 \%$ for seawater scrubbers and $0.5 \%$ to $1.5 \%$ for freshwater systems.

\section{Cold Ironing}

Cold ironing is the process of covering the energy demands of vessels at berth with power from the grid. Vessels that rely on shore power may switch off their auxiliary engines, and the only source of emissions during berth is the ship boilers that are used to maintain fuel temperatures. In the European Union, cold ironing has been used as an emissions abatement option for vessels at berth than must comply with the low-sulfur content requirement. In California, despite the lowsulfur requirement $(0.1 \%$ within $24 \mathrm{nmi}$ of the coast), cold ironing is mandatory for oceangoing vessels.

Although cold ironing has the potential to significantly reduce emissions generation at the port, there are important economic and environmental considerations. Induced emissions are generated at the power source (22). These will depend on the energy mixture powering the cold ironing facility. There are also transmission and energy conversion losses associated with cold ironing (2\% and $8 \%$, respectively) that must be included in calculations of energy cost and emissions generation.

\section{Liquefied Natural Gas}

Natural gas is an option that complies with the low-sulfur mandates. Dual-fuel engines have been designed that can use LNG for ship propulsion. In the past, only LNG carriers would use part of their cargo as fuel, to maintain the cargo tank pressure. The LNG carrier fleet has increased significantly in the past decade, and many ports now offer or plan LNG bunkering facilities. LNG has significant advantages as it results in lower emissions generation, higher fuel 
efficiency, and lower fuel costs than both MGO and HFO. LNG is expected to play a significant role as marine fuel for container ships in the future, especially for new vessels because fuel economy and compliance with regulations can outweigh higher building costs. The main challenge associated with LNG is that there are few bunkering ports at this stage. As of 2014, very few ports within ECAs offered LNG bunkering facilities (23), and for the purposes of this work the use of LNG as an abatement option is not relevant.

\section{METHODOLOGY}

This section presents the activity-based methodology used to model fuel consumption and emissions generation for each scenario. The cost-effectiveness of each option is examined in cost per ton of abated pollutant. The last criterion used in the analysis is estimation of the payback period for emissions reduction investments that are alternatives to the use of MGO.

\section{Fuel Consumption of Marine Engines}

Marine vessels require energy to sail and to power the onboard electricity demands (lighting, refrigerating, heating, communications, etc.). Each port-to-port trip can be decomposed into three main distinct activity phases: cruise, maneuvering, and hoteling at berth. An additional anchorage hoteling activity can occur when a vessel is held near the port until a berth or a pilot is available to process the vessel's arrival. These phases are depicted in Figure 2.

For each activity phase, dedicated engines on board provide the necessary power. The propulsion (or main) engines (variable $m$ ) operate during the cruise phase, auxiliary engines $(a)$ operate at all activity phases, and auxiliary boilers $(b)$ are used when the propulsion engines are not working (berth and maneuvering). Most activitybased methodologies estimate fuel consumption $\mathrm{FC}_{i, A, k}$ (kilograms) of engine $i$ onboard vessel $k$ during activity $A$, as in Equation 1 .

$$
\begin{aligned}
\mathrm{FC}_{i, A, k}=10^{-3} \cdot \mathrm{SFOC}_{i, A, k} \cdot \mathrm{EL}_{i, A, k} \cdot \mathrm{EP}_{i, k} \cdot t_{A, k} \\
\text { with } i \in(m, a, b) ; A \in(S, M, B)
\end{aligned}
$$

where

$$
\begin{aligned}
\mathrm{EL} & =\text { engine load } \\
\mathrm{EP} & =\text { installed engine power } \\
t & =\text { time of activity } \\
S & =\text { cruise phase } \\
M & =\text { maneuvering phase, and } \\
B & =\text { berth hoteling phase }
\end{aligned}
$$

Therefore, $\mathrm{FC}_{i, A, k}$ is a function of the installed engine power $\mathrm{EP}_{i, k}$ (kilowatts), and the engine loads $\mathrm{EL}_{i, A, k}$ are a percentage of maximum continuous rating, the time of activity $t_{A, k}$, and $\mathrm{SFOC}_{i, A, k}(\mathrm{~g} / \mathrm{kW}-\mathrm{h})$. During sailing, $\mathrm{EL}_{m, S, k}$ depends on the sailing speed, the weather conditions, and the amount of cargo loaded. In most studies $(5,6,7,21)$, a cubic relationship known as the propeller law is used to estimate the changes of engine load at different sailing speeds $V_{S 1}$ and $V_{S 2}$, as in Equation 2.

$$
\frac{\mathrm{EL}_{m, S, k}^{1}}{\mathrm{EL}_{m, S, k}^{2}}=\left(\frac{V_{S 1}}{V_{S 2}}\right)^{3}
$$

However, for container ships and vessels with higher average sailing speeds, higher exponents would be used. Values between 3.2 and 3.5 are suggested for medium-sized vessels (tankers, feeder container ships) and values up to 4.5 for fast container ships during extreme weather (24). For auxiliary engines, the value of $\mathrm{EL}_{a, S, k}$ varies depending on the time of operation (for lighting requirements) and the cargo carried (more power is required for additional reefer containers). Power requirements at berth will depend on the number of reefers, the time of operation, and the port visited. This study used average values of $30 \%$ for $\mathrm{EL}_{a, S, k}$ and $23 \%$ for $\mathrm{EL}_{a, B, k}$ used in previous work (15). Finally, the maneuvering activity phase has very different durations at different ports and for different vessels. An average value of $1 \mathrm{~h}$ per call was used (including departure and arrival), and for the power requirements the suggested values of the Port of Los Angeles, California, emissions inventory study were used. Finally, the SFOC value of any engine is a function of its operating load and will increase for low loads. This study used SFOC-EL curves as published by engine manufacturers to estimate these values for the various operating conditions $(25,26)$.

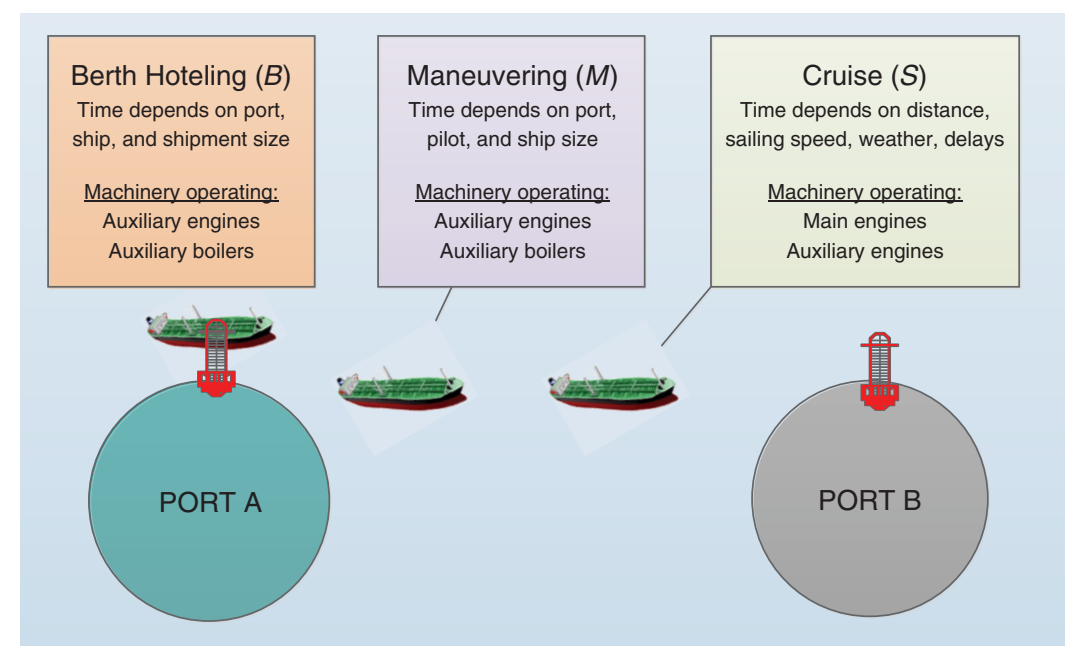

FIGURE 2 Activity phases of each trip and operating machinery. 


\section{Fuel Emissions Factors and Grid Emissions from Cold Ironing}

Emissions factors are used to link the amount of pollutant emissions released to the atmosphere with the quantity of fuel combusted during engine activity. Such factors are used when actual emissions data through measurements are not available.

\section{Fuel Emissions Factors}

Fuel emissions factors are unitless and defined as the weight of pollutant divided by the weight of the fuel that generated the pollutants. The emissions $\varepsilon^{j}(\mathrm{~kg})$ of pollutant species $j$ can be calculated by multiplying fuel consumption $\mathrm{FC}_{i, k}$ of engine $i$ on board vessel $k$ with the emissions factor $\mathrm{EF}^{i}$ :

$\varepsilon_{A}^{i}=\mathrm{FC}_{e, k} \cdot \mathrm{EF}_{e, k}^{i}$

This study used the emissions factors for $\mathrm{CO}_{2}$ as suggested from the third IMO greenhouse gas study, summarized in Table 1 (considering engine operation without the use of scrubber systems).

The $\mathrm{SO}_{2}$ emissions factors are proportional to the sulfur content present in the fuel. For MGO this value does not exceed $0.1 \%$, whereas for $\mathrm{HFO}$ the average value is $2.7 \%$. Nitrogen oxides $\left(\mathrm{NO}_{\mathrm{x}}\right)$ emissions factors used are suggested for Tier 1 ships. The various IMO levels of control for $\mathrm{NO}_{\mathrm{x}}$ emissions depend on the date of construction of the vessel specified in Regulation 13 of MARPOL Annex VI (4). Because this study considered investments of scrubbers as retrofitting options, the case studies refer to older vessels. Finally, particulate matter emissions are affected by the sulfur content in the fuel and are influenced by the operating loads of the engine with a significant increase at low loads.

\section{Grid Emissions Factors}

Grid emissions factors are expressed in grams of pollutant per kilowatt-hour of energy generated. With the exception of countries that rely heavily on fossil fuel and coal, the grid emissions factors are usually lower than the equivalent factors of fossil fuel used in internal combustion engines and marine engines in particular. The efficiency of the grid has been gradually improving over the years, aided by stricter regulations that require the increase of Renewable Energy Standard participation in the energy mixture. Cold ironing units in a port that powers vessels at berth produce no emissions, and offer an option that reduces local and regional pollution.

TABLE 1 Emissions Factors Used in Study

\begin{tabular}{lllll}
\hline & \multicolumn{4}{l}{ Emissions Factor $(\mathrm{g} / \mathrm{g}$ fuel) by Pollutant Species } \\
\cline { 2 - 5 } Fuel & $\mathrm{CO}_{2}$ & $\mathrm{SO}_{2}$ & $\mathrm{NO}_{\mathrm{x}}$ & $\mathrm{PM}$ \\
\hline HFO & 3.114 & $0.02 \cdot \mathrm{S} \%$ & Main engines: 0.087 & 0.00728 \\
MGO & 3.206 & $\mathrm{na}$ & Aux. engines: 0.057 & 0.00634 \\
LNG & 2.750 & 0.00002 & 0.0078 & 0.00018 \\
\hline
\end{tabular}

NoTE: na = not applicable; aux. = auxiliary.

\section{Cost Elements}

Scrubber Costs

Installation costs vary significantly depending on the size of the ship and engines. In 2005, for ships with main engine capacity above $15,000 \mathrm{~kW}$, typical capital costs were estimated at $\$ 147$ and $\$ 209 / \mathrm{kW}$ installed for new builds and retrofits, respectively (9). More recent figures on capital investment costs suggest a value of \$6 million for a feeder vessel with installed power of $16,750 \mathrm{~kW}$ and carrying capacity of 1,70020 -ft equivalent unit. It is possible, however, that these capital costs will drop as the technology matures.

\section{Cold Ironing Costs}

Older vessels need to be retrofitted to use cold ironing. Typical costs depend on the size and type of the vessel and range from $\$ 300,000$ to $\$ 2$ million. For European ports outside ECAs, where the only fuel requirements are at berth, cold ironing is more attractive. In contrast, for ships sailing in ECAs and therefore needing to comply with low-sulfur requirements at all activity phases (cruise, maneuvering, berth), investment in scrubber systems may be preferable.

\section{Payback Period}

The payback period of an investment is the time required to reach a break-even point. In other words. it indicates the necessary time until the net present value (NPV) of the investment is zero, and from that point onward the investment becomes profitable. The NPV is the sum of incoming and outgoing cash flows over a period of time that have been discounted back to the present value. With outgoing cash flows negative and incoming positive, the NPV ${ }^{i}$ of investment $i$ can be estimated as

$\mathrm{NPV}^{i}=\mathrm{CAPEX}^{i}+\sum_{t=0}^{N} \frac{B_{t}^{i}-\mathrm{OPEX}_{t}^{i}}{(1+r)^{t}}$

where

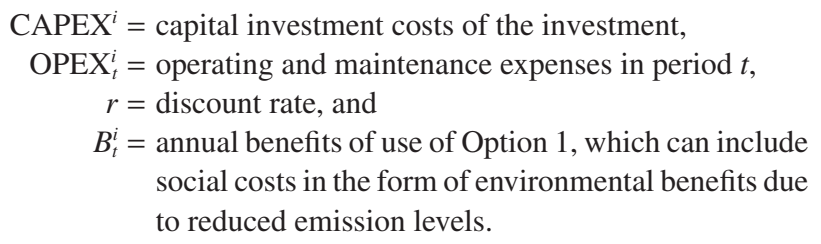

The payback period is used to analyze whether investing in a specific emissions abatement technology is a good option from the ship operator's perspective without considering social benefits in the economic analysis.

For ship operators, the decision lies in selecting the least expensive solution that ensures compliance with the regulation. The option of using low-sulfur fuel can be perceived as the do-nothing case, which will be compared with the options for investments in technology that will reduce operating costs. Therefore, the costs of installing scrubber systems will be contrasted with the price differential between MGO and HFO, allowing estimation of a payback time for the installation costs. 
TABLE 2 Specifications of Examined Ships

\begin{tabular}{|c|c|c|c|c|c|c|c|c|}
\hline \multirow[b]{2}{*}{ Ship } & \multirow[b]{2}{*}{ Capacity (TEU) } & \multirow[b]{2}{*}{$\mathrm{V}_{S}$ (knots) } & \multirow[b]{2}{*}{ Engine Speed } & \multirow[b]{2}{*}{$\mathrm{EP}_{m}(\mathrm{~kW})$} & \multirow[b]{2}{*}{$\mathrm{EP}_{a}(\mathrm{~kW})$} & \multicolumn{3}{|c|}{ Fuel Consumption $(\mathrm{kg})$ HFO No Scrubber } \\
\hline & & & & & & $\begin{array}{l}\text { Cruise } \\
\text { (per nmi) }\end{array}$ & $\begin{array}{l}\text { Maneuvering } \\
\text { (per call) }\end{array}$ & $\begin{array}{l}\text { Berth } \\
\text { (per hour) }\end{array}$ \\
\hline A & 1,500 & 13 & Medium & 4,200 & 800 & 48.3 & 102.5 & 96.5 \\
\hline $\mathrm{B}$ & 3,500 & 16 & Medium & 17,000 & 3,500 & 110.6 & 358.4 & 281.7 \\
\hline $\mathrm{C}$ & 5,000 & 19 & Slow & 36,000 & 7,400 & 230.4 & 720.2 & 493 \\
\hline
\end{tabular}

Note: $\mathrm{TEU}=20-\mathrm{ft}$ equivalent unit.

\section{Payback Period of Cold Ironing for the Ship}

The payback time of a decision to retrofit a vessel to receive shore power will depend on the price of fuel, the price of power, and the time spent at ports that provide power. A vessel that is retrofitted to use cold ironing may still use HFO or MGO (depending on the calling port) if it is cheaper. Therefore, for ports where the use of lowsulfur fuel is not mandatory, a provision of some monetary incentive may be necessary to convince ship operators to receive shore power.

\section{Payback Period of Cold Ironing for the Port}

Significant investments are required for port authorities that want to provide cold ironing technology, with initial capital costs estimated as between $\$ 1.5$ million and $\$ 3$ million per berth. From the ship operator's perspective, investing in cold ironing is an attractive option to reduce fuel costs at berth. Therefore, for ports where the use of low-sulfur fuel is mandatory, or where the cost of electricity is lower than the fuel costs of the auxiliary engines, cold ironing can be a viable solution. The drop in oil prices has not resulted in a similar reduction in electricity cost, and therefore ships that can use cold ironing may opt to use their auxiliary engines. This approach will increase the payback period of the port because the cold ironing berth is less used.

\section{Case Study}

Three container ships were selected for a cost-benefit analysis of abatement options for compliance with ECA regulations. All ships were Tier 1 vessels that spend a considerable amount of their time within ECAs. Their technical specifications are summarized in Table 2.

\section{Voyage Data}

Ship A has a weekly service that calls at Rotterdam, Netherlands; Dublin, Ireland; Felixstowe, United Kingdom; and Rotterdam again. The roundtrip distance is estimated at $1,308 \mathrm{nmi}, 53 \%$ of which is within the North Sea ECA. All ports are European and so there is a $0.1 \%$ sulfur requirement during berth. Ship B runs a biweekly service that calls at Tacoma, Washington; Anchorage and Kodiak, Alaska; and Tacoma again. The study assumed that $57 \%$ of this distance is within the North America ECA. Ship C is a conceptual case study assumed to operate between Gothenburg, Sweden, and Felixstowe, two times each week, and the entire distance is within the North Sea and the Baltic Sea ECAs. The voyage characteristics are shown in Table 3.

It was assumed that the selected routes did not change and there was no seasonal variation in the voyage frequency. The hours at berth are indicative according to published results of shipping companies operating these routes, and Table 3 summarizes the average berth and maneuvering duration. The analysis assumes that the engine loads were the same for each port and there was no seasonality in electricity requirements.

\section{Use of MGO Within ECAs and at Ports}

In this section, it is assumed that the ships use MGO as an abatement option when sailing in ECAs and when spending time at berth. Annual operating costs are summarized in Figure 3; average MGO and HFO prices for 2013 and 2015 are used for comparison.

Estimations of emissions savings were based on the emissions factors in Figure 3 and assuming that the freshwater scrubbers increase fuel consumption by $1.5 \%$ but reduce $\mathrm{SO}_{2}$ by $97 \%$ and particulate matter emissions by $45 \%$ if $\mathrm{HFO}$ is used. Use of MGO resulted in significantly higher $\mathrm{SO}_{2}$ emissions for Ship A; this result reflects that

TABLE 3 Summary of Voyages Examined for Baseline Case

\begin{tabular}{lcclrrrr}
\hline & & & & \multicolumn{2}{c}{ Cruise Distance (nmi) } & & \\
Ship & $\begin{array}{l}\text { Port Calls } \\
\text { per Year }\end{array}$ & $\begin{array}{l}\text { Berth Hours } \\
\text { per Call }\end{array}$ & ECA & ECA & Non-ECA & $\begin{array}{l}\text { Maneuvering } \\
\text { at Each Port (h) }\end{array}$ & $\begin{array}{l}\text { Annual Fuel } \\
\text { Consumption (tons) }\end{array}$ \\
\hline A & 156 & 13 & North Sea & 694 & 614 & 2.5 & $3,496.9$ \\
B & 78 & 21 & North America & 1,636 & 1,338 & 2 & $90,414.1$ \\
C & 208 & 9 & Slow & 1,046 & na & 2.5 & $26,136.5$ \\
\hline
\end{tabular}

Note: na = not applicable. 


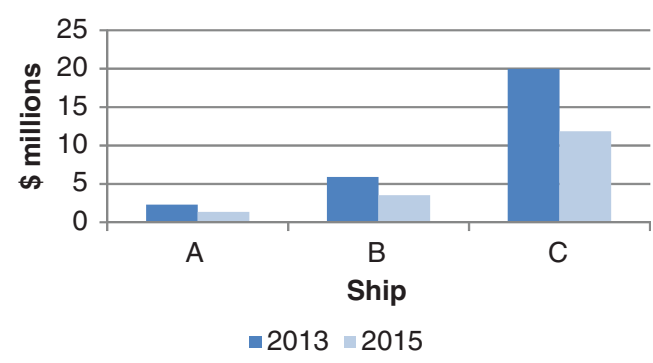

(a)

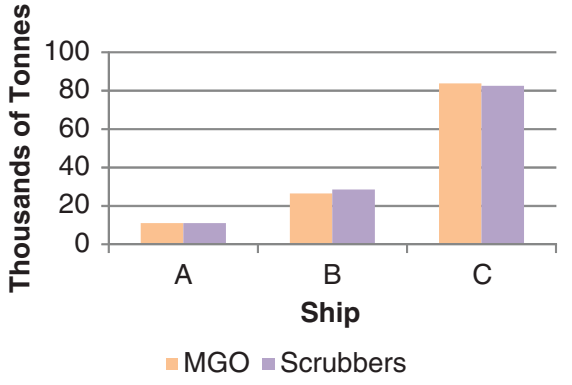

(b)

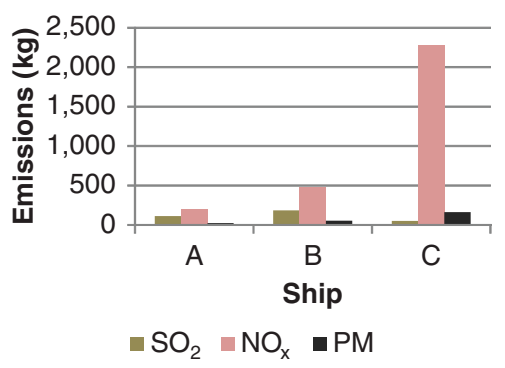

(c)

FIGURE 3 Annual factors for use of MGO versus scrubbers: (a) operation costs ( $\$$ millions), $(b) \mathrm{CO}_{2}$ (thousands of tonnes), and $(c)$ emissions $[\mathrm{kg}$.

the vessel spends considerable amounts of time operating outside an ECA.

\section{Scrubber Systems and Payback Period}

The results in Table 3 can be used to estimate the payback time of an investment in scrubber systems from each ship operator's perspective. This perspective considered only the annual fuel savings achieved following the installation of scrubbers. The annual costs in Figure 3 were considered in the respective year's values, and for this reason the CAPEX values for scrubber systems as estimated in the same year were $\$ 290$ and $\$ 358$ per kilowatt-hour. The discount rate $r$ was assumed to be 5\%, but this value may differ for various technological solutions. For example, the European Union awarded funding to a large ferry operator for the installation of scrubber systems on several vessels. Therefore, external funding for some technologies may make a particular solution more attractive for the decision maker.

The payback periods given in Table 4 were estimated without consideration for the loss of revenue while each vessel is being retrofitted and assuming that the investment is paid back only by the reduced operating costs.

Table 4 shows that the lowest payback period is for Ship C, mainly because it is assumed to sail only within an ECA. Ship B has the highest payback period, mainly because of its lower utilization in one year (in distance sailed). Table 4 shows that the low fuel prices in 2015 significantly increased the payback period for all ships. Therefore, a decision to invest in scrubbers in 2013 would be based on a payback period that would be shorter because of the expected increase in

\begin{tabular}{|c|c|c|}
\hline \multirow[b]{2}{*}{ Ship } & \multicolumn{2}{|c|}{$\begin{array}{l}\text { Payback Period } \\
\text { (years) by Year }\end{array}$} \\
\hline & 2013 & 2015 \\
\hline A & 4.2 & 9.7 \\
\hline B & 6.5 & 17 \\
\hline C & 2.3 & 5 \\
\hline
\end{tabular}

fuel prices. The case studies assumed that even in 2013, the alternative option would have been MGO. However, for the period of 2013 to 2015 , the use of fuel with a maximum sulfur content of $1 \%$ was allowed, with the exception of California waters (within $24 \mathrm{nmi}$ ) and European ports where $0.1 \%$ was required. Finally, the lifetime of the project was not considered, but because the average lifetime of container ships is 25 years and the examined ships were Tier 1 (constructed before 2001), the payback period in 2015 for Ship B suggests that investing in scrubbers may not be a good option.

\section{CONCLUSIONS AND RECOMMENDATIONS FOR FURTHER WORK}

This paper presented a conceptual approach to the issue of sulfur emissions abatement options available to ship owners. The results show that there are significant implications of the new sulfur limits for the payback period of emissions abatement investments, particularly following the unexpected drop in fuel prices. The decline in fuel prices, which resulted in the equation of current MGO prices to HFO prices of 2013, may have significantly delayed the payback period anticipated by ship and port operators that invested in technological solutions ahead of the new sulfur requirements. Therefore, a potential delay in the starting date of implementation of the new global sulfur limits $(0.5 \%)$ from 2020 to 2025 may also play a critical role in such investments. The suggested methodology would be enhanced by additional scenarios and sensitivity analyses on several key parameters: fuel price differential, use of LNG as fuel, variation in operating patterns (speed, engine load, time at berth), discount rates, and designation of additional ECAs before new global limits. A speed optimization approach for the fuel switching scenario would improve the accuracy of the cost-benefit analysis. The proposed analysis will allow ship operators to decide which technology option is better for a specific vessel and help policy makers better understand the effects of coming regulation.

\section{Effects of Slow Steaming on Payback Time}

This study did not consider explicitly the effects of a potential change in sailing speed on the payback period of such investments. In the case of scrubber systems, each installation reduces operating costs because of the lower fuel costs. However, as indicated by various studies in the literature, a potential decrease in sailing speed would result in significantly lower fuel consumption per voyage and in fewer voyages 
per year. Therefore, slow steaming may delay the payback time of such investments. In addition, most studies assumed that a vessel would have the same sailing speed whether it was running on MGO or using scrubber systems. An interesting next step is to examine the impact on payback time of an increase in sailing speed related to low fuel costs.

\section{Inclusion of Social Costs}

The inclusion of environmental improvements of emissions abatement of scrubbers versus MGO was proposed in previous studies $(20,27)$. These studies suggested the valorization of environmental benefits in terms of dollars per reduced ton of pollutant. Estimation of external costs is complex, and the values vary depending on area and pollutants. A potential impact of inclusion of the maritime sector in emissions trading schemes is a significant change to the payback time of such investments, as the social cost estimations of $\mathrm{SO}_{2}, \mathrm{NO}_{\mathrm{x}}$, and particulate matter emissions is extremely high (27). A critical question is whether to include environmental benefits of local pollutant reductions $\left(\mathrm{SO}_{\mathrm{x}}\right.$, particulate matter) that occur outside ECAs because of installed scrubber systems.

\section{REFERENCES}

1. Review of Maritime Transport. UNCTAD/RMT/2014. United Nations Conference on Trade and Development, 2014. http://unctad.org/en /PublicationsLibrary/rmt2014_en.pdf. Accessed June 2015.

2. Buhaug, Ø., J. Corbett, O. Endresen, V. Eyring, J. Faber, S. Hanayama, D. Lee, H. Lindstad, A. Mjelde, C. Palsson, W. Wanquing, J. Winebrake, and K. Yoshida. Second IMO Greenhouse Gas Study. International Maritime Organization, London, 2009.

3. Third IMO GHG Study. International Maritime Organization, London, 2014. http://www.iadc.org/wp-content/uploads/2014/02/MEPC-67-6 -INF3-2014-Final-Report-complete.pdf. Accessed June 2015.

4. Revised MARPOL Annex VI: Regulations for the Prevention of Air Pollution from Ships and NOx Technical Code. Marine Environmental Protection Committee, International Maritime Organization, London, 2008.

5. Cariou, P. Is Slow Steaming a Sustainable Means of Reducing $\mathrm{CO}_{2}$ Emissions from Container Shipping? Transportation Research Part D: Transport and Environment, Vol. 16, No. 3, 2011, pp. 260-264.

6. Psaraftis, H. N., and C.A. Kontovas. Balancing the Economic and Environmental Performance of Maritime Transportation. Transportation Research Part D: Transport and Environment, Vol. 15, No. 8, 2010, pp. 458-462.

7. Corbett, J. J., H. Wang, and J. J. Winebrake. The Effectiveness and Costs of Speed Reductions on Emissions from International Shipping. Transportation Research Part D: Transport and Environment, Vol. 14, No. 8, 2009, pp. 593-598.

8. The 0.1\% Sulphur in Fuel Requirement as from 1 January 2015 in SECAs: An Assessment of Available Impact Studies and Alternative Means of Compliance. European Maritime Safety Agency, Lisbon, Portugal, 2010.

9. Low Sulfur Marine Fuel Availability Study. Tetra Tech, Inc., and Ultra Systems, 2008. http://www.polb.com/civica/filebank/blobdload .asp?BlobID=5086. Accessed May 2015.
10. Entec UK Ltd. Service Contract on Ship Emissions: Assignment, Abatement, and Market-Based Instruments. Task 2c-SO2 Abatement. Directorate-General for Environment, European Commission, Brussels, Belgium, 2005.

11. Delhaye, E., T. Breemersch, K. Vanherle, J. Kehoe, M. Liddane, and K. Riordan. COMPASS-The Competitiveness of European Short-Sea Freight Shipping Compared with Road and Rail Transport. Transport and Mobility Leuven, Leuven, Belgium, 2010.

12. Notteboom, T. The Impact of Low Sulphur Fuel Requirements in Shipping on the Competitiveness of RORO Shipping in Northern Europe. WMU Journal of Maritime Affairs, Vol. 10, No. 1, 2011, pp. 63-95.

13. Lloyd's List Sulphur Survey: Distillate Fuels Seen as Best Solution for Meeting Sulphur Rules. 2015. http://www.1loydslist.com/11/sector /ship-operations/article460072.ece. Accessed June 2015.

14. Panagakos, G. P., E. V. Stamatopoulou, and H. N. Psaraftis. The Possible Designation of the Mediterranean Sea as a SECA: A Case Study. Transportation Research Part D: Transport and Environment, Vol. 28, 2014, pp. 74-90.

15. Zis, T., R. J. North, P. Angeloudis, W.Y. Ochieng, and M. G. Bell. The Environmental Balance of Shipping Emissions Reduction Strategies. In Transportation Research Record: Journal of the Transportation Research Board, No. 2479, Transportation Research Board, Washington, D.C., 2015, pp. 25-33.

16. Doudnikoff, M., and R. Lacoste. Effect of a Speed Reduction of Containerships in Response to Higher Energy Costs in Sulphur Emission Control Areas. Transportation Research Part D: Transport and Environment Vol. 28, 2014, pp. 51-61.

17. Fagerholt, K., N.T. Gausel, J.G. Rakke, and H.N. Psaraftis. Maritime Routing and Speed Optimization with Emission Control Areas. Transportation Research Part C: Emerging Technologies, Vol. 52, 2015, pp. 57-73.

18. Fagerholt, K., and H. N. Psaraftis. On Two Speed Optimization Problems for Ships that Sail In and Out of Emission Control Areas. Transportation Research Part D: Transport and Environment, Vol. 39, 2015, pp. 56-64.

19. Notteboom, T.E., and B. Vernimmen. The Effect of High Fuel Costs on Liner Service Configuration in Container Shipping. Journal of Transport Geography, Vol. 17, No. 5, 2009, pp. 325-337.

20. Jiang, L., J. Kronbak, and L. P. Christensen. The Costs and Benefits of Sulphur Reduction Measures: Sulphur Scrubbers Versus Marine Gas Oil. Transportation Research Part D: Transport and Environment, Vol. 28, 2014, pp. 19-27.

21. Henriksson, T. $\mathrm{SO}_{\mathrm{x}}$ Scrubbing of Marine Exhaust Gases. Wärtsilä Technical Journal, Feb. 2007.

22. Zis, T., R. J. North, P. Angeloudis, W.Y. Ochieng, and M. G. H. Bell. Evaluation of Cold Ironing and Speed Reduction Policies to Reduce Ship Emissions Near and at Ports. Maritime Economics and Logistics, Vol. 16, No. 4, 2014, pp. 371-398.

23. Holden, D. Liquefied Natural Gas (LNG) Bunkering Study. PP087423-4, Revision 3, 2014. http://www.marad.dot.gov/wp-content/uploads/pdf /DNVLNGBunkeringStudy3Sep14.pdf. Accessed July 2015.

24. Psaraftis, H. N., and C.A. Kontovas. Speed Models for Energy-Efficient Maritime Transportation: A Taxonomy and Survey. Transportation Research Part C: Emerging Technologies, 26, 2013, pp. 331-351.

25. SFOC Optimisation Methods for MAN B\&W Two-Stroke IMO Tier II Engines. MAN Diesel, 2010. http://mandieselturbo.com/files/news /filesof15180/5510-0099-00ppr_low.pdf. Accessed Nov. 2014.

26. Project Guide: Camshaft Controlled Two-Stroke Engines. MAN Diesel, 2009. http://www.mandieselturbo.com/download/project_guides_tier1 /printed/s50mc6.pdf. Accessed Sept. 2015.

27. Song, S. Ship Emissions Inventory, Social Cost and Eco-Efficiency in Shanghai Yangshan Port. Atmospheric Environment, Vol. 82, 2014 , pp. 288-297.

The Standing Committee on Marine Environment peer-reviewed this paper. 